\title{
Praktik mistisisme Jawa dalam novel Partikel karya Dewi Lestari
}

\author{
Arif Setiawan ${ }^{I^{*}}$, Musaffak ${ }^{2}$ \\ Program Studi Pendidikan Bahasa Indonesia, Fakultas Keguruan dan Ilmu Pendidikan, Universitas Muhammadiyah Malang, \\ J1. Tlogomas 246 Malang, Indonesia \\ 1 arifsetiawan@umm.ac.id ; musaffak@umm.ac.id² \\ *Corresponding author: arifsetiawan@umm.ac.id
}

\begin{tabular}{l}
\hline Sejarah Artikel Diterima: 2 September 2020 Direvisi: I9 Oktober 2020 Tersedia Daring: 3 I Oktober 2020 \\
ABSTRAK \\
\hline Mistisisme dalam tataran masyarakat Jawa menjadi sebuah simbol yang digunakan dalam kehidupan, terutama dalam konteks \\
beragama. Penelitian ini bertujuan untuk mendeskripsikan praktik mistisisme Jawa dalam novel Partikelkarya Dewi Lestari. \\
Hal ini didasari oleh realitas bahwa pengarang termasuk ke dalam generasi yang tumbuh dan berkembang di lingkungan \\
modern. Penelitian ini menggunakan metode deskriptif kualitatif, pendekatan yang digunakan adalah sosiologi sastra. \\
Sumber data penelitian ini adalah novel Partikel karya Dewi Lestari yang diterbitkan oleh PT Bentang Pustaka dengan \\
jumlah 490 halaman pada tahun 20I2. Data dalam penelitian ini mencakup satuan cerita yang terwujud dalam dialog, \\
monolog, paragraf, sekuen cerita, bagian kalimat, maupun narasi tokoh yang menggambarkan praktik mistisisme Jawa dalam \\
novel Partikelkarya Dewi Lestari. Pengumpulan data dilakukan dengan langkah (a) membaca sumber data; (b) unitizing (mengambil \\
data yang tepat dengan cara menandai teks; serta (c) mencatat dan menginventarisasi teks yang relevan. Setelah semua data terkumpul, \\
maka data dianalisis berdasarkan fokus penelitian yang lebih menekankan pada praktik mistisisme Jawa. Hasil penelitian \\
menunjukkan bahwa dalam novel Partikel karya Dewi Lestari menampilkan praktik mistisisme Jawa pada tataran \\
sarengat/syariat dan hakekat. Praktik mistisisme Jawa pada tataran sarengat/syariat dibuktikan dengan (I) percaya terhadap \\
jin \& setan dan (2) percaya pada mitos-mitos, sedangkan pada tataran hakekat dibuktikan dengan percaya dan upaya yang \\
dilakukan tokoh untuk menjumpai Tuhan. Berdasarkan hasil penelitian, maka dapat ditarik kesimpulan bahwa praktik \\
mistisisme Jawa dalam novel Partikelkarya Dewi Lestari pada tataran sarengat/syariat dan hakekat.
\end{tabular}

Kata Kunci Hakekat, Praktik mistisisme, Syariat

\section{ABSTRACT}

Mysticism in the Javanese society has become a symbol in life, especially in the religious context. This study aimed at describing the practice of Javanese mysticism in Dewi Lestari's novel, Partikel. It is based on the reality that the author belongs to a generation that grows and develops in a modern environment. This research employed the descriptive qualitative method and the sociology of literature approach. The data source was the novel Partikel by Dewi Lestari published by PT Bentang Pustaka in 2012 with a total of 490 pages. The data included story units manifested in dialogue, monologue, paragraphs, story plots, sentence sections, and characters' narratives describing the practice of Javanese mysticism. The data collection was done by (a) reading the data source; (b) unitizing (retrieving the right data by marking the text; and (c) recording and inventorying the relevant texts. The data were then analysed based on a research focus that emphasized the practice of Javanese mysticism. The results showed that the practice of Javanese mysticism is at the level of sarengat/sharia and hakekat. The practice of Javanese mysticism at the sharia level is evidenced by (I) believing in jinn $\&$ demons and (2) believing in myths. Meanwhile, in the tarekat level, it is proven by the character's trust and efforts to meet God. Finally, it can be concluded that the practice of Javanese mysticism in the novel Partikel by Dewi Lestari is present at the level of sharia and tarekat.

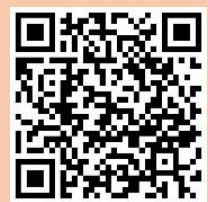

Copyright@2020, Arif Setiawan \& Musaffak This is an open access article under the $\mathrm{CC}-\mathrm{BY}-3.0$ license

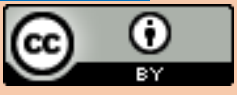

\begin{tabular}{ll}
\hline Keywords & Hakekat, Practice of mysticism, Sharia \\
\hline \hline How to Cite & Setiawan, A. \& Musaffak, M. (2020). Praktik mistisisme Jawa dalam novel Partikel karya Dewi \\
& Lestari. KEMBARA: Jurnal Keilmuan Bahasa, Sastra, dan Pengajarannya (e-Journal), 6(2). 267-278. doi: \\
& https://doi.org/I0.222I9/kembara.v6i2.I5249
\end{tabular}

\section{PENDAHULUAN}

Suku Jawa merupakan suku terbesar yang mendiami wilayah Indonesia. Keberadaan suku ini bukan hanya di pulau Jawa tetapi juga menyebar merata di seluruh Nusantara. Suku Jawa terkenal dengan keramahtamahan dan kehalusannya (Mujib, 2016; Siburian \& Malau, 2018; Wijayanti \& Nurwianti, 
20II). Seperti sebagian besar pendudukan di Indonesia, masyarakat Jawa lebih banyak yang memeluk agam Islam (Bakri, 20I4). Kondisi tersebut tidak dapat digunakan sebagai tolak ukur untuk melihat kenyataan di lapangan. Hal ini dikarenakan banyaknya masyarakat Jawa yang menjadi pemeluk Islam memiliki perbedaan secara kultural yang disebabkan oleh variasi subkultural di lingkungan masyarakat Jawa sendiri (Murjiyono, 2004; Setiawan, 2019). Kondisi subkultural yang terjadi di lingkungan masyarakat Jawa telah berperan dalam membentuk persepsi sebagian besar masyarakat Jawa yang masih mempercayai mitos-mitos dan legenda leluhur (Nawafi, 2020; Setiawan, 2015). Kepercayaan tersebut diwujudkan dalam sebuah ilmu kebatinan dan juga mistisisme (Mulder, 2013). Ilmu kebatinan dan mistisisme tersebut diwujudkan dalam bentuk simbol-simbol yang digunakan dalam kehidupan terlebih konteks beragama (Murjiyono, 2004). Simbol-simbol tersebut dijadikan sebagai pola dan falsafah dalam kehidupan bagi masyarakat Jawa (Mashadi, 2013; Nawafi, 2020). Hal itu, tercermin pada konsep hidupnya dalam memandang hubungan dengan Tuhan, sesama manusia, dan alam (Wahidi, 2013), sehingga penggunaan simbol menjadi sangat penting sebagai media dalam proses penyatuan diri antara Tuhan, manusia, dan alam (Nawafi, 2020).

Simbol dalam budaya Jawa merupakan suatu kaitan yang tak terpisahkan dengan agama dan budaya asli Jawa secara keseluruhan (Alfan, 2017; Miswari, 2017). Simbol dijadikan juga sebagai pegangan bagi penganut mistisisme Jawa, karena mistisisme Jawa mendasarkan aspek kehidupannya pada simbol-simbol (Mashadi, 2013; Miswari, 2017). Selain itu, simbol juga digunakan sebagai sebuah perjalanan batin untuk mendapatkan kesempurnaan diri dalam penyatuannya dengan Tuhan dalam konteks mistisisme Jawa (Rudin, 2017). Secara umum mistisisme Jawa merupakan sebuah upaya penebusan serta pengetahuan mengenai alam raya dengan tujuan mengadakan hubungan langsung antara individu dengan Tuhan, sesama manusia, dan lingkungan (Wahidi, 2013). Berdasarkan konsep tersebut, maka dapa ditarik satu kesimpulan bahwa mistisisme Jawa tidak berdasarkan pada doktrin tertentu, melainkan proses berdasarkan pengalaman hidup masing-masing individu (Mashadi, 20I3). Pengalaman hidup yang membawa sebuah keyakinan dan religiositas yang bersifat pribadi, sehingga pada tataran ini semua urusannya bersifat sangat individu (Alfan, 2017). Keyakinan dan religiositas yang bersifat pribadi tentunya memiliki pola dan kadar yang berbeda-beda pada setiap individunya (Furqon \& Busro, 2017).

Pada tataran praktik, mistisisme Jawa merupakan upaya yang dilakukan oleh individu untuk mencapai tahap kepercayaannya (Alfan, 2017). Upaya yang dilakukan sebagai bentuk pencarian tunggal manusia yang menghendaki penyatuan kembali dengan asalnya (Penciptanya), sebagai bentuk pelepasan terhadap segala bentuk ikatan duniawi (Mulder, 2013; Rudin, 2017). Perjalanan atau pencarian mistik yang dilakukan manusia harus dilakukan melalui empat tahapan yang kompleks yaitu, syariat, hakekat, tarekat, dan makrifat, keempatnya merupakan tahapan secara prosedural dalam mistisisme Jawa (Mulder, 2013). Mistisisme Jawa dari sudut pandang Mulder yang sampai dengan hari ini telah dijadikan sebagai sebuah dasar dan landasan bagi sebagian masyarakat Jawa dalam konteks keyakinan dan kepercayaan, sehingga masih menjadi pedoman dasar bagi individu dalam menjalani kehidupan (Furqon \& Busro, 2017). Sebagai pedoman dasar bagi individu, mistisisme Jawa dalam praktiknya telah menjadi salah satu muatan yang mencolok dalam beberapa karya sastra di era milenial. Salah satu karya sastra yang menunjukkan praktik mistisisme Jawa adalah novel Partikel karya Dewi Lestari.

Novel Partikel merupakan karya sastra yang dihasilkan oleh sastrawan muda Indonesia yang memuat permasalahan yang sesuai dengan kehidupan sehari-hari. Berdasarkan kondisi tersebut terdapat beberapa alasan yang melatarbelakangi pemilihan novel Partikel karya Dewi Lestari sebagai objek kajian dalam penelitian ini. Novel Partikel merupakan salah satu dari 6 novel dalam seri Supernova yang telah ditulis oleh Dewi Lestari. Pada novel seri Supernova terlihat betapa kejelian Dewi Lestari dalam memadukan beberapa unsur pembangun di dalamnya seperti sains, filsafat, biologi, religiositas yang dibalut dengan indahnya proses percintaan yang membuat keenam serial Supernova memiliki kelebihan yang begitu menarik untuk dibaca. Balutan unsur yang disajikan oleh Dewi Lestari dalam serial Supernova bukan satu-satunya hal yang menjadikan alasan mengapa novel Partikel dipilih dan digunakan sebagai objek kajian. Pertimbangan lain yang menjadi dasar dalam menetapkan pilihan pada novel Partikeladalah 
penghargaan yang telah diukir oleh Dewi Lestari. Sebagai penulis muda, Dewi Lestari telah mendapatkan banyak penghargaan yang meliputi (I) 5 besar Khatulistiwa Literary Award 2006, (2) penghargaan sastra Badan Pengembangan dan Pembinaan Bahasa 2012, (3) Anugerah Pembaca Indonesia 2015 untuk kategori buku fiksi terfavorit, dan (4) IKAPI Awards 2018 untuk kategori Book of The Year 2018 "Aroma Karsa".

Berdasarkan unsur pembangun novel, novel Partikel karya Dewi Lestari sangat menarik untuk diteliti, karena memiliki benang merah dengan praktik mistisisme Jawa yang ada di tengah masyarakat jawa dewasa ini. Novel Partikel berlatar di pinggir Kota Bogor, di dekat kampung bernama Batu Luhur yang menjadi awal cerita panjang perjalanan seorang anak bernama Zahra Amala, putri seorang dosen di ITB. Zahra kecil tidak mendapatkan pendidikan formal layaknya teman-teman seusianya yang telah mengenyam bangku sekolah. Zahra kecil, tidak pernah merasakan hal itu, karena Firas selaku ayahnya telah memilih untuk mendidik dan membesarkan Zahra dengan pendidikan secara eksklusif dari Firas. Melalui penelitian yang tengah digeluti oleh Firas, cerita panjang dimulai dengan melibatkan sebuah daerah angker dan terlarang di daerah Batu Luhur yaitu Bukit Jambul. Firas dan Zahra seringkali terlihat keluar masuk Bukit Jambul yang menurut masyarakat sekitar adalah tempat paling angker, penuh dengan mitos, dan tempat bersemayam jin dan setan yang tidak boleh dikunjungi siapa pun. Sampai pada suatu hari ketika Firas hilang dan tidak pernah ditemukan kembali keberadaannya, setelah terakhir kali diketahui masuk ke Bukit Jambul pada malam hari. Mendapati kondisi tersebut, Zahra mencoba mencari ayahnya dengan masuk ke Bukit Jambul, namun usaha tersebut tidak pernah membuahkan hasil. Kondisi tersebut menjadikan Zahra semakin penasaran, sehingga melakukan pencarian di tegah kesepian yang dialaminya. Jalan panjang yang telah dilewati Zahra, membawanya sampai pada tempat baru yang sangat mengubah hidupnya melalui ritual yang bernama iboga. Berdasarkan paparan mengenai unsur pembangun novel, maka penelitian ini memiliki tujuan untuk menganalisis dan mendeskripsikan praktik mistisisme Jawa berdasarkan tahapan mistisisme menurut Mulder (2013) yang meliputi (I) syariat/sarengat, (2) hakekat, (3) tarekat, dan (4) makrifat.

Masing-masing tahapan praktik mistisisme Jawa dapat dijabarkan sebagaimana berikut, tahap sarengat/syariat merupakan tahapan yang paling dasar dalam eksistensi mistisisme, pada tahapan ini semua hal lebih diarahkan pada bentuk percaya terhadap keberadaan dewa, dukun, roh, jin, setan, mitosmitos serta benda-benda mitologi yang berupa keris, panah, pedang, dan tombak (Mulder, 2013). Tahap hakekat merupakan tahapan dimana ibadah yang telah dilakukan bukan hanya sekedar menggerakan anggota tubuh dan melafalkan bacaan, melainkan sebagai upaya yang dilakukan untuk menjumpai Tuhan dalam keberadaan diri yang paling dalam (Mulder, 2013). Tahap tarekat, merupakan perilaku yang mengedepankan individu jika melanggar larangan Tuhan, maka yang terjadi dalam kehidupan pribadi menjadi tidak sesuai dengan kaidah keagamaan, sehingga apa yang dilakukan mengalami kehambaran atau kehilangan maknanya (Mulder, 2013). Tahap makripat, merupakan tahapan yang paling tinggi karena tujuan setiap individu telah menyatu dengan Tuhan (Mulder, 2013).

Penelitian terdahulu mengenai mistisisme telah dilakukan oleh peneliti lain diantaranya (Furqon \& Busro, 2017; Gunawan, 2016; Mulder, 2013; Murjiyono, 2004; Nawafi, 2020; Rudin, 2017; Sulaeman, 2019; Thohir, 2013; Wahidi, 2013) yang mengaji mistisisme berdasarkan kaitannya antara mistisisme sebagai produk budaya dan mistisisme dalam konteks agama utamanya Islam. Sudut pandang lain mengenai mistisisme berkaitan dengan tradisi yang telah mengakar dan menjadi identitas budaya juga telah dilakukan oleh (Endraswara, 2006; Mashadi, 2013; Nur, 2020; Setiawan, 2019). Penelitian terkait mistisisme yang terdapat dalam sebuah karya baik sastra dan film juga telah dilakukan oleh (Ningrum \& Saksono, 2020; Nisa, 2019; Setiawan \& Musaffak, 2019; Widijanto, 2018; Yusantia, Laila, \& Rahmat, 2019).

Berdasarkan beberapa penelitian terdahulu yang telah dilakukan, penelitian ini memiliki kebaruan yang belum pernah dilakukan oleh penelitian terdahulu. Kebaruan penelitian ini bersandar pada kajian mengenai praktik mistisisme Jawa yang didasarkan pada pendapat Mulder (2013) yang terdiri dari (I) syariat/sarengat, (2) hakekat, (3) tarekat, dan (4) makrifat. Kebaruan selanjutnya adalah dari sisi objek 
kajian yang digunakan yaitu novel Partikel karya Dewi Lestari, sepengetahuan penulis belum ada penelitian mengenai mistisisme dengan menggunakan objek kajian novel Partikel karya Dewi Lestari, sehingga ini juga menjadi nilai kebaruan kedua dalam penelitian ini. Selain nilai kebaruan yang telah dipaparkan tersebut, kajian terhadap praktik mistisisme Jawa dalam novel Partikelkarya Dewi Lestari juga dapat memperluas jaringan pemikiran intelektual di bidang kajian mistisisme Jawa, khususnya tahapan dalam praktik mistisisme Jawa di tengah masyarakat yang meliputi tahapan (I) syariat/sarengat, (2) hakekat, (3) tarekat, dan (4) makrifat.

\section{METODE}

Berdasarkan tujuan penelitian yang telah dipaparkan, metode yang digunakan adalah metode deskriptif kualitatif. Metode ini digunakan untuk mendeskripsikan dan menginterpretasikan data-data yang tertulis dalam novel Partikel karya Dewi Lestari. Jenis penelitian ini adalah kualitatif, sedangkan pendekatan yang digunakan dalam penelitian ini adalah sosiologi sastra. Sumber data penelitian ini adalah novel Partikel karya Dewi Lestari yang diterbitkan oleh PT Bentang Pustaka dengan jumlah 490 halaman pada tahun 2012. Data dalam penelitian ini mencakup satuan cerita yang terwujud dalam dialog, monolog, paragraf, sekuen cerita, bagian kalimat, maupun narasi tokoh yang menggambarkan praktik mistisisme Jawa dalam novel Partikel karya Dewi Lestari. Pengumpulan data dilakukan dengan langkah berdasarkan pedoman pengumpulan data yang telah dikemukakan oleh Creswell (2014) yang terdiri dari yaitu (a) membaca sumber data; (b) unitizing (mengambil data yang tepat dengan cara menandai teks; dan (c) mencatat dan menginventarisasi teks yang relevan.. Model analisis data yang digunakan adalah flow model of analysis yang dikemukakan oleh (Miles \& Huberman, 1994). Di mana proses kerjanya dilakukan dengan langkahlangkah (I) seleksi data, (2) paparan data, dan (3) penarikan kesimpulan.

\section{HASIL DAN PEMBAHASAN}

Pada bagian hasil dan pembahasan akan diuraikan analisis data terkait dengan praktik mistisisme Jawa yang digambarkan dalam novel Partikelkarya Dewi Lestari. Kutipan data dalam novel yang terkait dengan praktik mistisisme Jawa selanjutnya akan diinterpetasikan kembali menurut kajian teori mistisisme Jawa Mulder (2013) untuk melihat detail substansi tentang praktik mistisisme Jawa.

\section{Parktik Mistisisme Jawa Tahapan Syareat dalam Bentuk Percaya pada Jin \& Setan}

Masyarakat Jawa sebagai masyarakat yang telah tumbuh dan berkembang dengan tradisi dan kultur yang telah mengakar erat dalam segala kondisi. Hal ini juga berpengaruh terhadap perilaku masyarakat yang sangat mempercayai hal-hal yang bersifat gaib seperti percaya pada jin dan setan dalam setiap kehidupannya, yang dibuktikan melalui kutipan data berikut.

Ada yang bilang, pohon-pohon di sana "hidup" dan punya kekuatan sakti, barang siapa mencoba menebang pohon di sana langsung kesurupan sebelum berhasil menancapkan kapak untuk kali kedua. Ada yang bilang, hutan itu markas Prabu Siliwangi dan pasukan gaibnya. Versi lebih bombastis lain bilang, di sana adalah pusat jin satu dunia berkumpul (SBPJS ${ }^{4}$, Lestari, 20I2:29).

Kutipan SBPJS ${ }^{4}$ menunjukkan bahwa praktik mistisisme Jawa yang terdapat dalam novel Partikel karya Dewi Lestari berupa percaya pada jin dan setan. Kepercayaan pada jin dan setan telah tertanam dengan baik di tengah masyarakat Jawa, sehingga apapun yang berkaitan dengan hal di luar rasionalitas selalu dikaitkan pada keberadaan jin dan setan. Hampir sebagian besar masyarakat Jawa sangat memegang teguh kepercayaan tersebut dan telah menerapkan dalam kehidupan sehari-hari. Hal ini juga terlihat jelas dalam kutipan SBPJS4, masyarakat di sekitar Bukit Jambul masih sangat mempercayai keberadaan jin dan setan. Bentuk kepercayaan tersebut berupa informasi yang meluas dari mulut ke mulut, bahwa di Bukit Jambul tidak ada satu orang pun yang dapat menebang pohon. Setiap kali ada orang yang akan menebang pohon pasti langsung kesurupan. Selain kesurupan, seringkali orang yang menebang pohon juga melihat 
posisi pohon yang berpindah-pindah dari posisi awalnya. Dua hal itu masih sebagian kecil dari hal yang ditunjukkan oleh Bukit Jambul pada masyarakat Batu Luhur. Kepercayaan lain yang telah diyakini oleh masyarakat, Bukit Jambul adalah tempat bersemayam Prabu Siliwangi dengan semua pasukan gaibnya. Kepercayaan tersebut tidak aneh karena kondisi demografis antara Bukit Jambul dengan kerajaan Pasundan yang hanya terpisah jarak dalam hitungan ratusan kilometer saja. Kepercayaan terhadap Prabu Siliwangi telah menancap erat pada diri masyarakat di sekitar bekas kerajaan Pasundan, sehingga kepercayaan tersebut dihadirkan dengan baik oleh pengarang untuk memberikan warna tersendiri dalam melihat praktik mistisisme Jawa di masyarkat Batu Luhur.

Belum cukup dengan kesurupan, pohon yang berpindah-pindah, dan keberadaan Prabu Siliwangi. Bukit Jambul telah menghadirkan banyak kepercayaan di luar nalar semua orang di Batu Luhur, versi lain yang cukup menggemparkan adalah kepercayaan bahwa Bukit Jambul merupakan tempat berkumpulnya jin dari seluruh dunia. Kepercayaan tersebut tidak begitu saja terbangun di tengah masyarakat, melainkan berangkat dari banyaknya kejadian aneh dan tidak masuk akal yang terjadi di Bukit Jambul. Kejadian aneh yang begitu banyak, telah membuat setiap orang meyakini bahwa Bukit Jambul memiliki kekuatan magis tersendiri yang berasal dari jin dan setan yang ada di dalamnya. Segala bentuk kepercayaan pada kutipan SBPJS $^{4}$ menjadi salah satu representasi praktik mistisisme Jawa yang digambarkan dengan baik oleh pengarang dalam novel Partikel, sehingga menjadi salah satu unsur pembangun cerita yang menarik. Selain itu, kepercayaan terhadap Prabu Siliwangi menjadi bukti nyata bahwa praktik mistisisme Jawa masih menjadi warna tersendiri yang tetap melekat di tengah masyarakat.

Aisyah melahirkan anak setengah ular. Anak itulah tumbal Bukit Jambul yang tertunda. Seharusnya tumbal itu Firas, tapi akhirnya berpindah ke generasi berikutnya. Abah Hamid dikutuk tidak bisa lagi punya garis keturunan laki-laki. Versi lain mengatakan, Firas sudah punya istri jin di Bukit Jambul. Makanya ia jadi jarang pulang. Kandungan Aisyah "dikerjai" oleh istri jin-nya Firas yang cemburu (SBPJS ${ }^{6}$, Lestari, 2012:46).

Kutipan SBPJS ${ }^{6}$ menunjukkan bahwa kepercayaan terhadap jin dan setan masih melekat erat di masyarakat Jawa. Setiap kejadian aneh yang dialami oleh diri sendiri dan orang-orang terdekat selalu dikaitkan dengan kekuatan yang tidak dapat dirasionalkan, namun malah dikaitkan dengan kepercayaan yang telah mengakar erat di masyarakat. Segala sesuatu yang telah mengakar dengan baik di masyarakat Jawa juga ditangkap oleh pengarang sebagai salah satu bentuk praktik mistisisme Jawa. Hal ini dibuktikan dengan kutipan SBPJS ${ }^{6}$ yang menunjukkan bahwa asumsi masyarkat Batu Luhur terkait dengan kelahiran tidak normal yang terjadi pada putra Firas. Menanggapi kejadian tersebut, banyak bermunculan informasi dalam berbagai versi, informasi yang santer dipercayai adalah kandungan Aisyah dikerjai oleh istri jin-nya yang cemburu. Informasi tersebut sedemikian cepat menyebar ke seluruh masyarakat Batu Luhur, sehingga banyak asumsi yang bermunculan di tengah masyarakat. Nada miring seketika merebak bahwa istri Firas telah melahirkan anak setengah ular, karena sebagian besar tubuh bayi memiliki kulit yang kering dan berwarna hijau. Kejadian tersebut coba dikaitkan dengan Bukit Jambul yang selama ini dikeramatkan oleh masyarakat Batu Luhur.

Tidak sampai di situ saja, sebagian masyarakat Batu Luhur mempercayai apa yang terjadi pada Aisyah merupakan kutukan yang dilakukan oleh penghuni Bukit Jambul yang tidak lain adalah bangsa Jin dan Setan. Lebih jauh lagi, nada miring juga meluncur dari masyarakat Batu Luhur yang mengatakan bahwa istri jin Firas merasa cemburu dengan Aisyah yang tengah mengandung, sehingga kehamilan Aisyah dikerjai oleh jin dari Bukit Jambul. Bahkan kejadian tersebut juga dikaitkan dengan kepercayaan terhadap kutukan yang tengah menimpa keluarga Abah Hamid yang tidak akan punya keturunan laki-laki. Kutipan SBPJS $^{6}$ telah memberikan informasi penting mengenai praktik mistisisme masyarakat Jawa dalam kehidupan sehari-hari. Hal ini ditunjukkan melalui kepercayaan terhadap kejadian aneh yang tidak dapat dilogikakan sebagai akibat dari kekuatan jin dan setan di Bukit Jambul. Kepercayaan yang dimiliki oleh masyarakat Batu Luhur ini merupakan representasi praktik mistisisme Jawa yang digambarkan dengan baik oleh pengarang. Praktik mistisisme yang digambarkan merupakan salah satu tahapan pada praktik 
mistisisme dalam bentuk syariat, yang merupakan tahapan paling awal dalam bingkai mistisisme Jawa menurut Mulder.

\section{Parktik Mistisisme Jawa pada Tahapan Syareat dalam Bentuk Percaya pada Mitos-mitos}

Praktik mistisisme yang dilakukan masyarakat Jawa tidak hanya terbatas pada percaya kepada jin dan setan saja, melainkan juga percaya terhadap mitos-mitos yang secara tradisi telah turun temurun. Bentuk praktik mistisisme Jawa selanjutnya tergambar melalui kepercayaan pada mitos-mitos yang telah turun temurun diwariskan oleh nenek moyang, hal tersebut dapat dilihat pada kutipan berikut.

... Bagaimanapun, Ayah adalah jaminan hidup atas perjanjian tak tertulis Kampung Batu Luhur dengan kekuatan yang bersemayam di tempat angker itu. Menggunjingkan dan berspekulasi adalah hal terjauh yang bisa penduduk lakukan (SBPM², Lestari, 20I2:33).

Mitos yang berkembang di Batu Luhur adalah perjanjian yang tidak tertulis antara Firas dengan semua kekuatan yang terdapat dalam Bukit Jambul. Bukit Jambul adalah salah satu tempat angker sampai detik ini bagi masyarakat Batu Luhur, karena kepercayaan tersebut masyarakat Batu Luhur selalu memiliki versi mereka sendiri setiap kali ada orang yang melakukan kontak dengan Bukit Jambul. Seperti yang ditunjukkan dalam kutipan $\mathrm{SBPM}^{2}$, masyarakat telah memiliki versi mereka sendiri mengenai apa yang tengah dialami oleh Firas. Banyak yang menyatakan bahwa Firas adalah jaminan dari sebuah perjanjian yang tidak tertulis antara Batu Luhur dengan seribu kekuatan yang bersemayam di Bukit Jambul. Salah satu buktinya adalah mudahnya Firas keluar masuk Bukit Jambul tanpa ada sesuatu yang terjadi padanya. Gunjingan tersebut hampir setiap hari selalu menjadi teman setia bagi Firas dan Zahra, karena hanya mereka berdua yang memang sering keluar masuk Bukit Jambul dengan begitu mudah. Sejauh ini masyarakat Batu Luhur hanya dapat melakukan spekulasi dengan Bukit Jambul yang angker. Selain itu, mereka juga mengaitkan kejadian yang ditimpa Firas dan Zahra sebagai perjanjian tidak tertulis Batu Luhur dengan kekuatan gaib di Bukit Jambul. Kepercayaan akan keangkeran Bukit Jambul begitu dipegang erat oleh masyarakat Batu Luhur, sehingga menjadi sebuah kesalahan apabila menganggap kepercayaan tersebut sebagai sesuatu yang biasa dan tidak ada artinya. Kutipan berikut juga menunjukkan bahwa kepercayaan masyarakat Batu Luhur terhadap Bukit Jambul sangat terlihat jelas.

\footnotetext{
"Katanya, orang yang menebang pohon di sini langsung kesurupan, Yah."

"Hutan ini memang tidak sembarangan." Nada suaranya berubah berat. Dan ia terdengar seperti menjauh.

"Ayah?” Segera aku sadar, sungguh tak bijak berteriak di tempat ini. Dan kesadaranku selanjutnya adalah, Ayah tak akan menjawab. Aku cukup kenal ayahku untuk tahu bahwa dia mampu meninggalkanku sendirian, di hutan paling angker sekalipun ( $\mathrm{SBPM}^{5}$, Lestari, 20I2:6I).
}

Pada suatu malam, Firas mengajak Zahra untuk menembus semak belukar yang lebat dan tajam di Bukit Jambul. Sambil berbisik, Firas ingin menunjukkan pada Zahra bahwa ada temuan baru mengenai fungi yang ada di dalam Bukit Jambul. Pada malam sebelumnya Firas telah menemukan hal baru yang ditunjukkan oleh fungi. Tentu saja temuan baru tersebut tidak akan dilewatkannya begitu saja, serta harus segera mengajak Zahra untuk mengetahui temuan tersebut. Pada malam berikutnya Firas mengajak putrinya (Zahra) untuk melihat temuan barunya tentang fungi di Bukit Jambul. Firas dan Zahra berjalan pelan meninggalkan rumah menuju Bukit Jambul, sembari disinari cahaya remang bulan pada malam hari. Zahra menjadi orang yang begitu semangat berjalan menuju Bukit Jambul karena keingintahuannya pada temuan baru ayahnya. Sembari berjalan menuju Bukit Jambul, Zahra berdiskusi pelan dengan Firas, setiap kali ada orang yang menebang pohon di Bukit jambul selalu mengalami kesurupan dan kejadian aneh lainnya. Suara Firas terdengar keras untuk mengiyakan pertanyaan Zahra tadi, samar-samar suara Firas tiba-tiba menghilang dan semakin menjauh dari Zahra. Sesegera mungkin Zahra sadar kalau memang ayahnya telah meninggalkannya dalam perjalanan menuju tempat fungi yang telah dijanjikan oleh Firas. 
Di tengah kondisi Bukit Jambul yang gelap dan sunyi tidak mungkin Zahra berteriak minta tolong, dan itu bukan cara yang selama ini juga diajarkan oleh Firas kepadanya. Zahra cukup kenal dengan karakter Firas yang selalu memberikan kejutan dalam setiap penemuan barunya, kali ini kejutan yang diberikan oleh Firas adalah dengan cara meninggalkan Zahra di tengah Bukit Jambul yang angker. Hal itu dilakukan Firas bukan tanpa alasan, pasti ada hal yang ingin diajarkan pada Zahra dengan meninggalkannya di tengah perjalanan menuju tempat penemuan fungi. Pelajaran yang ingin diajarkan Firas pada Zahra adalah untuk tidak mudah menyerah dengan keadaan, tidak mudah takut, dan selalu berpikir secara rasional. Hari apa yang telah diajarkan pada Zahra sengaja diterapkan dalam perjalanan menuju tempat fungi. Satu hal yang dapat dipetik sebagai sebuah pelajaran berharga bagi Zahra adalah, kepercayaan pada mitos Bukit Jambul yang angker dapat dilawan dengan logika dan keberanian.

\section{Praktik Mistisisme Jawa pada Tahapan Hakekat dalam Bentuk Perilaku yang Percaya pada Tuhan}

Tahapan kedua pada praktik mistisisme Jawa adalah hakekat, pada tahapan ini setingkat lebih tinggi dari tahapan sarengat/syariat. Pada tahapan ini setiap individu yang melakukan praktik mistisisme Jawa tidak lagi hanya memiliki kepercayaan pada beberapa hal yang berbau gaib, melainkan setingkat lebih tinggi pada tataran bagaimana untuk berjumpa dengan Tuhan, sebagaimana pada kutipan berikut.

"Abah lantas melakukan rangkaian sembahyang khusus untuk meminta petunjuk. Suatu malam sesudah salat istikharah, ia diberi mimpi. Dalam mimpinya, ada sinar menyilaukan turun di puncak Bukit Jambul. Sinar itu ternyata semacam pemangsa. Ia menelan Ayah, kemudian sinar itu hilang begitu saja ditelan gelap. Ada suara yang menerangkan kepada Abah bahwa itulah yang terjadi kepada Ayah jika Bukit Jambul diusik (HBPPT², Lestari, 2012:33).

Mendengar kabar hilangnya Firas, Abah Hamid mencoba berpikir tenang dan tidak gegabah dalam mengambil keputusan tentang kabar hilangnya Firas. Sebagai seorang muslim yang baik dan taat, Abah Hamid kemudian melakukan serangkaian sembahyang khusus untuk mencari petunjuk atas hilangnya Firas. Melalui sembahyang khusus dan salat istikharah yang dilakukan oleh Abah Hamid, kemudian datang mimpi mengenai kejadian yang tengah menimpa Firas. Dalam mimpi tersebut seberkas cahaya yang mengilat begitu cepat turun di puncak Bukit Jambul, seberkas cahaya yang muncul dalam mimpi Abah Hamid berbwujud seperti sosok pemangsa. Seberkas cahaya tersebut memberikan isyarat pada Abah Hamid bahwa dialah yang telah menelan Firas dan menghilangkan jejak Firas di tengah belantaranya Bukit Jambul, seberkas sinar tersebut kemudian hilang dengan begitu saja ditelan gelapnya malam. Hilangnya seberkas sinar tersebut masih menyisahkan suara samar-samar yang menjelaskan pada Abah Hamid bahwa pesan tadi merupakan konsekuensi logis yang akan diterima oleh setiap orang yang mengusik Bukit Jambul. Jawaban yang muncul melalui mimpi tersebut merupakan sebuah janji pasti yang telah disampaikan oleh Allah, bahwa dalam mengambil setiap keputusan haruslah dilakukan dengan salat istikharah. Melalui salat istikharah, setiap pilihan dan pertanyaan akan suatu hal akan mendapatkan jawabannya melalui mimpi, entah itu dalam bentuk mimpi yang baik atau sebaliknya.

Potongan cerita pada kutipan HBPPT ${ }^{2}$ menjelaskan, bahwa pada tahapan hakekat setiap manusia telah mengalami satu langkah yang lebih baik untuk melaksanakan kepercayaannya terhadap Tuhan. Pada tataran ini ditunjukkan dengan apa yang telah dilakukan oleh Abah Hamid dalam upayanya mencari jawaban atas hilangnya Firas. Melalui keyakinan yang telah dipraktikkan dengan sepenuh hati dalam melaksanakan salat istikharah, maka didapatkan jawaban yang telah diminta dalam doa melalui salat istikharahnya. Selain itu, salat istikharah yang dilakukan oleh Abah Hamid adalah bentuk nyata dari tingkatan kepercayaan yang dilakukan dengan sepenuh hati sebagai sebuah usaha untuk menemui Tuhan. Hal ini tidak dapat dilakukan oleh semua orang, hanya sebagian orang yang dapat melakukannya di tengah orang lain tengah tertidur pulas di malam hari. Hal ini menunjukkan bahwa tahapan hakekat merupakan tahapan yang lebih kompleks daripada hanya sekedar mempercayai keberadaan Tuhan, tanpa disertai dengan usaha yang murni untuk mendekatkan diri padanya. Bentuk kepercayaan lain terhadap Allah dan rasul-Nya juga ditunjukkan pada kutipan data berikut. 
"Dengan segala kesombonganmu, kamu boleh menghina siapa pun di muka bumi ini, Zarah. Tapi jangan sekali-kali kamu menghina agamaku dan Rasulku," suara Abah yang menggelegar terdengar gemetar. "Kamu ... bukan cucuku lagi! (HBPPT", Lestari, 2012:43).

Kondisi di rumah semakin kalut, karena sampai beberapa hari Firas tidak juga menunjukkan tanda-tanda akan kembali ke rumah. Tentu saja ini menjadi sebuah hal yang sangat menyesakkan bagi semua anggota keluarga yang dengan cemas menunggu kepulangannya Firas yang telah menghilang selama satu minggu. Suasana kalut yang terjadi semakin membuat setiap orang yang berada di rumah kehilangan ketenangan dalam menghadapi semua permasalahan. Hal ini terlihat jelas dari sikap dan gelagat Abah Hamid yang mulai kehilangan kontrol menanggapi setiap ucapan yang disampaikan Zahra. Setiap penjelasan yang disampaikan Zahra selalu membuat Abah Hamid merasa naik darah, apalagi penjelasan Zahra selalu menunjukkan tanda kedangkalan berpikir dari sisi agama dan kepercayaan. Sampailah di suatu pertanyaan yang disampaikan oleh Abah Hamid pada Zahra, yang kemudian dijelaskan dengan pemahaman Zahra yang memang memandang segala sesuatunya hanya dari sisi sains tanpa mengaitkan dengan sisi religious. Mendengar jawaban dari Zahra, rasanya kesabaran Abah Hamid telah sampai pada titik terendah, sehingga tanpa diduga muncul pernyataan yang membuat seisi rumah merasa terhenyak. Abah Hamid berdiri berbicara dengan suara yang gemetar mengutuk apa yang telah dijelaskan oleh Zahra. Boleh kamu menyombongkan ilmu pengetahuanmu, namun jangan sekali-kali kami hina agama dan Rasulku, pernyataan tersebut menunjukkan rasa hormat yang tinggi terhadap keyakinan yang sudah dianut Abah Hamid sedari kecil. Cukup jangan dilanjutkan lagi apa yang sudah kamu ketahui tentang semua yang telah diajarkan oleh ayahmu selama ini. Itu semua telah melukai dan menghina agama dan Rasulku, cukup dan hentikan semua karena mulai sekarang engku bukan cucuku lagi. Pernyataan Abah Hamid seketika telah menjadikan seisi ruangan terasa sunyi dan beku.

Apa yang telah dilakukan oleh Abah Hamid menunjukkan bahwa setiap ilmu yang dipelajari pasti ada sumber yang mendasarinya. Terlebih ilmu adalah salah satu hal yang selalu ditekankan oleh agama Islam sebagai pegangan yang kuat. Namun kali ini, ilmu yang telah dipelajari oleh cucunya menunjukkan kedangkalan dalam berpikir dan mengaitkan ilmu dengan sisi religiositas. Bagi Abah Hamid, siapapun boleh belajar ilmu apapun, namun jangan sampai ilmu tersebut digunakan untuk menghina agama dan Rasulnya, karena keduanya merupakan sebuah kepercayaan yang tidak dapat dibandingkan dengan apapun yang berada di dunia ini. Sikap tersebut menunjukkan representasi praktik mistisisme Jawa pada tataran hakekat, yang merupakan tahapan bagaimana cara untuk dapat menemui Tuhan tanpa menunjukkan usaha yang murni dan penyerahan diri sepenuhnya untuk mendekatkan diri pada-Nya.

Hasil penelitian mengenai praktik mistisisme Jawa dalam novel Partikel karya Dewi Lestari dapat dibandingkan dengan hasil penelitian sebelumnya. Perbandingan temuan masalah dengan kajian yang sama, dapat dilihat dari hasil penelitian (Setiawan \& Musaffak, 2019). Berdasarkan hasil penelitian yang sudah dilakukan sebelumnya dapat ditarik titik persinggungan dengan kajian praktik mistisisme Jawa pada novel Partikel. Titik persinggungannya adalah pada mistisisme Jawa yang disampaikan oleh Mulder. Temuan pada penelitian sebelumnya mengungkapkan bahwa tokoh yang digambarkan oleh pengarang memiliki kepercayaan pada keberadaan hal-hal yang diluar logika atau berbau gaib, sehingga setiap menemui suatu kondisi baru maka bentuk kepercayaan terhadap hal bebaru gaib selalu menjadi pegangan utama. Eksistensi mistisisme pada tokoh yang digambarkan oleh pengarang apabila disesuaikan dengan tahapan mistisisme menurut Mulder masih berada pada tahapan syariat/sarengat. Hal ini dibuktikan dengan percaya pada semua hal yang berbau gaib dimanapun berada, baik itu percaya pada arwah nenek moyang, percaya pada mitos-mitos yang telah ada di masyarakat, serta percaya pada keberadaan jin dan setan. Eksistensi tersebut sejalan dengan hasil penelitian ini yang memang sudah menjalankan praktiknya pada tahapan syariat/sarengat yang dibuktikan dengan kejadian-kejadian aneh yang dialami oleh orang yang mencoba mengusik Bukit Jambul. Temuan ini menjadi pembeda dengan kajian yang sebelumnya dilakukan oleh (Setiawan \& Musaffak, 2019) yang hanya mengaji eksistensi mistisisme Jawa saja, 
sedangkan penelitian ini lebih menekankan pada tataran praktik mistisisme Jawa yang dilakukan oleh tokoh dalam novel Partikel karya Dewi Lestari.

Hasil penelitian praktik mistisisme Jawa juga dapat dibandingkan dengan penelitian yang dilakukan oleh (Nisa, 2019). Penelitian yang dilakukan oleh Nisa mengaji motif dan eksistensi mistisisme dalam novel Misteri Perawan Kubur, Dendam Iblis Cantik, dan Dosa Turunan karya Abdullah Harahap. Motif mistisisme yang dilakukan oleh tokoh terbagi menjadi dua yaitu motif egoistis dan motif positif, kedua motif tersebut dilakukan oleh tokoh untuk mendapatkan apa yang menjadi keinginannya. Motif egoistis dilakukan tokoh dalam bentuk samadi/semedi, guna mendapatkan keinginan yang bersifat pribadi, sedangkan motif yang bersifat positif dilakukan untuk membantu memecahkan masalah orang lain serta menghancurkan sarana magis yang buruk. Kedua motif tersebut merupakan representasi kehidupan di tengah masyarakat yang ditunjukkan oleh pengarang dalam ketiga objek kajian yang digunakan sebagai sumber data. Dimana dalam setiap perilaku seseorang harus didasari dengan konsep yang berlaku untuk diri sendiri dan kebaikan orang lain. Temuan kedua adalah eksistensi mistisisme yang digambarkan dalam bentuk tapa dan meditasi yang khusuk untuk mencapai inti batin. Kekhusukkan yang dilakukan oleh setiap individu dalam melakukan tapa atau meditasi merupakan salah satu syarat mutlak yang harus dilakukan oleh siapa pun untuk menjumpai sang pencipta-Nya. Tanpa adanya kekhusukkan dalam rangkaian ibadah atau tapa yang dilakukan, mustahil inti atau makna ibadah tersebut dapat dilakukan dengan sepenuh hati. Temuan penelitian yang dilakukan oleh Nisa (2019) bila dibandingkan dengan penelitian ini terlihat beberapa perbedaan, perbedaan tersebut terletak pada motif dan eksistensi yang melandasi setiap perbuatan yang dilakukan dengan orientasi individu maupun sosial yang bermuara pada hal yang bersifat positif.

Tahapan mistisisme Jawa di era modern seperti sekarang, telah banyak mengalami pergeseran dalam praktiknya. Pergeseran tersebut dapat dilihat pada hasil penelitian Yusantia et al. (2019) yang menunjukkan bahwa unsur mistis berupa (I) hal gaib yang diyakini, (2) unsur mistis yang berupa sebabakibat yang tidak rasional, dan (3) unsur mistis berupa mitos. Temuan tersebut apabila dibanding dengan mistisisme Jawa yang disampaikan oleh Mulder, tentu hanya termasuk pada tahapan yang pertama saja yaitu syariat/sarengat. Tahapan syariat/sarengat juga terdapat dalam penelitian ini, namun yang menjadi pembeda adalah praktik mistisisme Jawa yang dilakukan oleh tokoh sudah sampai pada tahapan yang kedua yaitu hakekat. Pada tahapan hakekat praktik mistisisme Jawa harus dilakukan dengan dasar khusuk, sehingga dapat menyentuh batin sebagai sarana untuk bertemu dengan Tuhan. Tahapan kedua ini yang telah mengalami pergesaran cukup signifikan pada era modern seperti sekarang. Hal ini dikarenakan praktik tahapan hakekat membutuhkan kesungguhan atau kekhusukkan dianggap sulit, sehingga kebanyakan masyarakat hanya sebatas percaya terhadap segala sesuatu yang bersifat gaib tanpa ada langkah kongkret yang harus dilakukan untuk mewujudkannya.

\section{SIMPULAN}

Berdasarkan hasil analisis yang telah dilakukan dalam penelitian ini, dapat disimpulkan bahwa praktik mistisisme Jawa dalam novel Partikelkarya Dewi Lestari digambarkan pada tahap sarengat/syariat dan hakekat. Pada tahap sarengat/syariat praktik mistisisme Jawa diwujudkan dalam bentuk perilaku yang percaya pada jin \& setan seta percaya pada mitos-mitos. (I) Perilaku yang percaya pada jin \& setan ditemukan dalam bentuk setiap orang yang akan menebang pohon di Bukit Jambul pasti berakhir dengan kesurupan, karena Bukit Jambul adalah tempat bersemayam Prabu Siliwangi dan tentara gaibnya. (2) Perilaku percaya pada mitos-mitos ditemukan dalam bentuk perjanjian tak tertulis antara warga Batu Luhur dengan Bukit Jambul, bahwa siapa saja yang mengusik Bukit Jambul pasti akan mengalami kejadian aneh. Tahap kedua dalam praktik mistisisme Jawa adalah hakekat, pada tahapan ini diwujudkan dalam bentuk perilaku yang percaya pada Tuhan. Perilaku yang percaya pada Tuhan ditemukan dalam bentuk salat istikharah memegang teguh kepercayaan pada rasul, salat istikharah merupakan salat sunah yang dilaksanakan pada sepertiga malam dengan didasari kekhusukkan sebagai salah satu bentuk komunikasi pada Tuhan. Percaya kepada rasul merupakan salah satu pegangan dalam agam Islam yang memang harus 
dilakukan oleh setiap individu. Bentuk kepercayaan tersebut tidak hanya meyakini keberadaan rasul, namun juga meyakini setiap ajaran yang diajarkan merupakan kebenaran hakiki yang tidak dapat disangkal dengan apapun.

\section{UCAPAN TERIMA KASIH}

Penulis mengucapkan terima kasih kepada Direktorat Penelitian dan Pengabdian pada Masyarakat (DPPM) Universitas Muhammadiyah Malang yang telah memberikan dukungan dalam penelitian ini. Penulis juga mengucapkan terima kasih kepada semua pihak yang telah berkontribusi dalam penelitian ini, sehingga penelitian ini dapat terlaksana dan diselesaikan dengan baik.

\section{DAFTAR PUSTAKA}

Alfan, M. (2017). Perjumpaan mistisisme Jawa dengan Islam Syifa al-Qulub, 2(I), 44-55. Retrieved from:

https://dIwqtxtsIxzle7.cloudfront.net/5740II73/Perjumpaan_mistisme_jawa_dengan_isla m.pdf? I537259338=8response-content-

disposition=inline $\% 3 \mathrm{~b}+$ filename\%3dperjumpaan_mistisme_jawa_dengan_islam.pdf\&expires= I6I0666285\&signature $=$ ey2gyghhwanc04kubuxysyvetitoI wjn-

qwn2by7zctde7azqi3i6xpqrgtodavrnemlvigqreioj6snI fvvckduchbdircvvggnu 7lgiiqzwdhpgbi6w Oxrevasqkhrl8hp $\sim$ vucjksz-

gpyovzlvhqdto Ixab9f7r3dmnrrupgam0mskax54a20zstyzg29jbrt9g6o-

rqtkzblt3pitvnvjkcb6Isd88w8qd6c3usihoclvp19tq8zohzs $\sim$ iq9asqvbiyz $\sim$ tq8s6gmo3yfh3dzla21

qjnjwokott4zkn3gbi e2bfgvr8xp63oc22oue6gv6prufk78wxnyor4bq_\&key-pair-

id=apkajlohf5ggslrbv4za

Bakri, S. (20I4). Kebudayaan Islam bercorak Jawa (Adaptasi Islam dalam kebudayaan Jawa). DINIKA, I2(2), 33-40. Retrieved from: https://dIwqtxtsIxzle7.cloudfront.net/48947084/3kebudayaan-islam-bercorak-jawa-by-syamsul-bakri.pdf? I474257502=\&response-content-

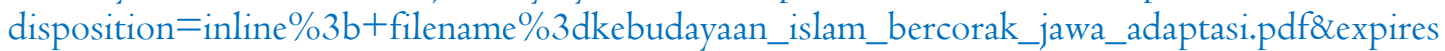

$=\mathrm{I} 6106625068$ signature $={ }_{s} 5 \mathrm{n} 4 \mathrm{I}$ 6odznh49gags16p0yqdkriyd8fpwkrrohf6eaospgv8hfbvgcjjnd

Ipqyihuymd5haweklpbhsgcIhi-

wbxooyfod fvzaifymjxsfzzis4svep3s7ofcwfon3psI I 5qci5szxyadbt jmrhf9kjx2qpfh8nvxxjwsc y 4 irex $\sim$ smzlulbermbdyhgdtpaikbay-

ie4etfwtu4fdw5 pivhxo484cqq5buz6iwgq5itjazrhxzzklxxpntg3qqijjo Iyeutyixkxujujrigo2va3h5a nm0-afzmx79gvibbfee9yIozobfp6lmhpitcvrvpn3qtukdr $\sim g 11$ t8mq_\&key-pair-

id=apkajlohf5ggslrbv4za

Creswell, J. W. (20I4). Research design: Qualitative, quantitative and mixed methods approaches. Thousand Oaks, CA: Sage Publications Inc.

Endraswara, S. (2006). Mistisisme dalam seni spiritual bersih desa di kalangan penghayat kepercayaan. Jurnal Kejawen, I(2), 38-57.

Furqon, S., \& Busro, B. (2017). Doktrin mistisisme Al-Ghazali (sufisme sebagai etape perjalanan spiritual). Syifa al-Qulub, 2(I), 35-46. doi: https://doi.org/I0.15575/saq.v2iI.2392

Gunawan, A. (2016). Produksi naskah dan mistisisme aksara dalam Bhīma Svarga. Manuskripta, 6(I), II-39. doi: https:// doi.org/I0.33656/manuskripta.v6iI.64

Lestari, D. (2012). Partikel. Yogyakarta: PT Bentang Pustaka

Mashadi, M. (2013). Konteks dan corak mistisisme Islam dalam tradisi keagamaan masyarakat Gorontalo. Ulumuna, I7(2), 259-274. doi: https://doi.org/I0.204I4/ujis.vI7i2.I62

Miles, M. B., \& Huberman, A. M. (1994). Qualitative data analysis: An expanded sourcebook. Los Angeles: Sage.

Miswari, M. (2017). Filosofi komunikasi spiritualitas: Huruf sebagai simbol ontologi dalam mistisme Ibn 'Arabī. Jurnal Al-Hikmah, 9(I4), I2-30. doi: https://doi.org/I0.32505/hikmah.v8iI.397 
Mujib, M. M. (2016). Fenomena tradisi ziarah lokal dalam masyarakat Jawa: Kontestasi kesalehan, identitas keagamaan dan komersial. IBDA: Jurnal Kajïan Islam dan Budaya, I4(2), 204-224. Retrieved from: file:///c:/users/lenovo/downloads/673-Article\%20Text-I45I-I-I020161002.pdf

Mulder, N. (20I3). Mistisisme Jawa ideologi di Indonesia. Yogyakarta: LKiS.

Murjiyono, Y. (2004). Mistisisme Jawa pesrspektif fenomenologi agama suatu perbandingan antara mistisisme Jawa, Hindu dan Islam. Studia Philosophica et Theologica, 4(I), 19-33. doi: https://doi.org/I0.353I2/spet.v4iI.I32

Nawafi, A. Y. F. (2020). Titik temu mistisisme Islam dan mistisisme Jawa; Studi analitis terhadap persinggungan ajaran tasawuf dan kejawen. Jurnal Intelektual: Jurnal Pendidikan Dan Studi Keislaman, IO(2), 242-254. doi: https://doi.org/I0.33367/ji.vI0i2.I297

Ningrum, P. S. W., \& Saksono, L. (2020). Mistisisme puisi Johann Wolfgang Von Goethe dalam WestÖstlicher Divan. Identitaet, $\quad(\mathrm{I})$, I-II. Retrieved from: https://jurnalmahasiswa.unesa.ac.id/index.php/identitaet/article/view/34056/30367

Nisa, A. (2019). Motif dan eksistensi mistisisme dalam novel Misteri Perawan Kubur, Dendam Iblis Cantik, dan Dosa Turunan karya Abdullah Harahap Jurnal Sapala, 5(I), I-I7. Retrieved from: https://jurnal.unesa.ac.id/index.php/jurnal-sapala/article/view/28528/26I06

Nur, A. (2020). Mistisisme tradisi mappadendang di Desa Allamungeng Patue, Kabupaten Bone. Jurnal Khitah: Kajian Islam, Budaya dan Humaniora, I(I), I-I6. Retrieved from: http:/ / ejournal.hmigowaraya.org/index.php/jurnalkhitah/article/view/2/pdf

Rudin, T. (2017). Ajaran taoisme dan mistisisme Islam (studi komparatif). Jurnal Intelektualita: Keislaman, Sosial dan Sains, 6(2), 27I-294. doi: https://doi.org/I0.19109/intelektualita.v6i2.I6II

Setiawan, A. (20I5). Sikap hidup wanita Jawa dalam novel Bekisar Merah dan novel Midah Si Manis Bergigi Emas. KEMBARA: Jurnal Keilmuan Bahasa, Sastra, dan Pengajarannya (e-Journal), I(I), I-I5. doi: https://doi.org/I0.22219/kembara.vIiI.2326

Setiawan, A. (2019). Mistisisme sebagai bentuk literasi budaya di kalangan masyarakat Jawa. Paper presented at the SENASBASA (Seminar Nasional Bahasa dan Sastra), Malang

Setiawan, A., \& Musaffak, M. (2019). Eksistensi mistisisme dalam novel Amba karya Laksmi Pamuntjak KEMBARA: Jurnal Keilmuan Bahasa, Sastra, dan Pengajarannya (e-Journal), 5(2), I46-I56. doi: https://doi.org/10.22219/kembara.v5i2.9672

Siburian, A. L. M., \& Malau, W. (2018). Tradisi ritual bulan suro pada masyarakat Jawa di Desa Sambirejo Timur Percut Sei Tuan. Gondang: Jurnal Seni dan Budaya, 2(I), 28-35. doi: https://doi.org/I0.24II4/gondang.v2iI.9764

Sulaeman, M. (2019). Mistisisme Jalal Al-Din Al-Rumi dalam Perspektif Annemarie Schimmel. Jurnal Ilmiah Spiritualis: Jumal Pemikiran Islam dan Tasawuf, 5(2), I53-I8I. Retrieved from: http://ejurnal.iaipd-nganjuk.ac.id/index.php/spiritualis/article/view/66/5I

Thohir, U. F. (20I3). Pemikiran mistisisme Annemarie Schimmel. Ulul Albab: Jurnal Studi Islam, I3(2), 203-2I8. doi: https://doi.org/IO.I8860/ua.v0i0.2376

Wahidi, A. (2013). Mistisisme sebagai jembatan menuju kerukunan umat beragama. Ulul Albab: Jurnal Studi Islam, I4(2), I35-I46. doi: https://doi.org/I0.I8860/ua.vI4i2.2653

Widijanto, T. (20I8). Dunia halus mistis Jawa dan fantasi magis Ternate dalam Godlob dan Cala Ibi. Jentera: Jurnal Kajian Sastra, 7(I), I02-I29. doi: https:/ / doi.org/I0.26499/jentera.v7iI.682

Wijayanti, H., \& Nurwianti, F. (20II). Kekuatan karakter dan kebahagiaan pada suku Jawa. Jurnal Psikologi, 3(2), II4-I22. Retrieved from: https://ejournal.gunadarma.ac.id/index.php/psiko/article/view/227/I70

Yusantia, D., Laila, A., \& Rahmat, W. (2019). Mistik dalam novel Gentayangan Pilih Sendiri Petualangan Sepatu Merahmu karya Intan Paramaditha (Tinjauan sosiologi sastra). Jurnal Bahasa: Bahasa dan 
Vol. 6, No. 2, Oktober, 2020, Halaman: 267-278

ISSN : 2442-7632 print | 2442-9287 online

278
KEMBARA: Jurnal Keilmuan Bahasa,

Sastra, dan Pengajarannya

Sastra Indonesia serta Pengajarannya, I(I), I9-27. doi:

https://doi.org/I0.26499/bahasa.vIiI.24 